\title{
Comparison between the mercury contamination in populations of Unio pictorum mancus (Mollusca, Bivalvia) from two lakes of different trophic state: the oligo-mesotrophic Lake Maggiore and the eutrophic Lake Candia
}

\author{
Oscar RAVERA*, Gian Maria BEONE ${ }^{1)}$, Maria Chiara FONTANELLA, Nicoletta RICCARDI and Ilenia CATTANI ${ }^{1)}$ \\ CNR - Institute of Ecosystem Study, Largo Tonolli 50, I - 28922 Verbania Pallanza, Italy \\ ${ }^{1)}$ Università Cattolica del Sacro Cuore, Istituto di Chimica Agraria e Ambientale, Via E. Parmense 84, 29100 Piacenza, Italy \\ *e-mail corresponding author: oscar.ravera@ise.cnr.it
}

\begin{abstract}
This research was designed to evaluate the influence of mussel (Unio pictorum mancus) size on mercury concentration in mussel soft tissues. It also evaluated the relationships between calcium, mercury and selenium in the mussel tissues. The mussel populations from the deep, meso-oligotrophic Lake Maggiore and the shallow, eutrophic Lake Candia were analyzed. The mean concentration of mercury in the tissues was $0.075 \mathrm{mg} \mathrm{kg}^{-1}$ in Lake Maggiore mussels and $0.033 \mathrm{mg} \mathrm{kg}^{-1}$ in Lake Candia mussels. The local mercury

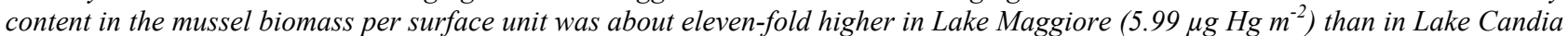
$\left(0.55 \mu \mathrm{g} \mathrm{Hg} \mathrm{m}^{-2}\right)$. This wide difference was due firstly to the larger population density (46.86 vs 6.93 ind $\left.\mathrm{m}^{-2}\right)$ and secondly to the higher individual content ( 0.128 vs $0.079 \mu \mathrm{g} \mathrm{Hg} \mathrm{ind}{ }^{-1}$ ) in Lake Maggiore than in Lake Candia. These differences in population density and individual mercury content are the result of both biological and environmental characteristics. Lake trophy and water renewal affect population density and individual growth rate, and ultimately determine their impact on biogeochemical cycles by regulating the mussel standing stock. The relationships between mercury, calcium and selenium were taken into account.
\end{abstract}

Key words: freshwater mussel, trophic degrees, total and organic mercury, calcium, selenium

\section{INTRODUCTION}

Some decades ago Boyden (1977) identified two major lines of progress in research on metal contamination in mussels. The first aimed to predict the maximal permissible concentration of a metal in edible species, and the second focused on the identification of species with characteristics qualifying them to be used as metal indicators. A third line, involving metal speciation and the synergic and antagonist effects produced by metal interactions, is still in progress and has been for some decades.

It is obviously important to compare the metal concentrations in different species living in the same environment; but it is just as important to compare the metal content in populations belonging to the same species and settled in different environments. In fact, it is from studies on this subject that the influence of the environment on contamination at population level may be estimated. Starting from this premise, the present study focused on the relationships between mercury concentration and the size of mussels belonging to two populations of the same species (Unio pictorum mancus) living in two lakes with a different trophic level: the oligomesotrophic Lake Maggiore and the eutrophic Lake Candia.

Mercury, calcium and selenium and their interactions are one of the subjects of this study. Mercury was considered because of its toxicity; along with cadmium and lead, it is regarded as the most toxic metal by national and international norms. Since mercury concentrations in the water of both lakes are too low $\left(\leq 0.005 \mu \mathrm{g} \mathrm{L}^{-1}\right)$ to damage mussel populations, we did not have to take into account the direct effects of mercury on the mussel metabolism. Calcium was considered because of the important role it plays in the metabolism of all the community species, particularly that of shelled molluscs. In addition, the mercury taken up by molluscs is primarily bound by the calcareous granules in the soft tissues.

Selenium and mercury are different because selenium is a non-metal belonging to the calcogenic group, whereas mercury is a transition metal of the B group. Both of these elements may produce stable complexes. Selenium, like mercury, is present in the environment also in methylated forms and consequently is available to the biota.

There is agreement on the important role played by selenium in the detoxification and mobilisation/immobilisation processes of mercury (Byrne \& Vesk 2000; Chen et al. 2001; Belzile et al. 2006,). In fact, one of the treatments proposed to reduce the effects of mercury contamination in water bodies, and in particularly the mercury concentration in biota, is the addition of a low concentration of selenium $\left(<1 \mu \mathrm{g} \mathrm{L}^{-1}\right)$ (Turner \& Rudd 1983).

One of the most important factors controlling mercury concentration in aquatic organisms is primary production. Rudd \& Turner (1983) tried to reduce mercury contamination by stimulating primary production 

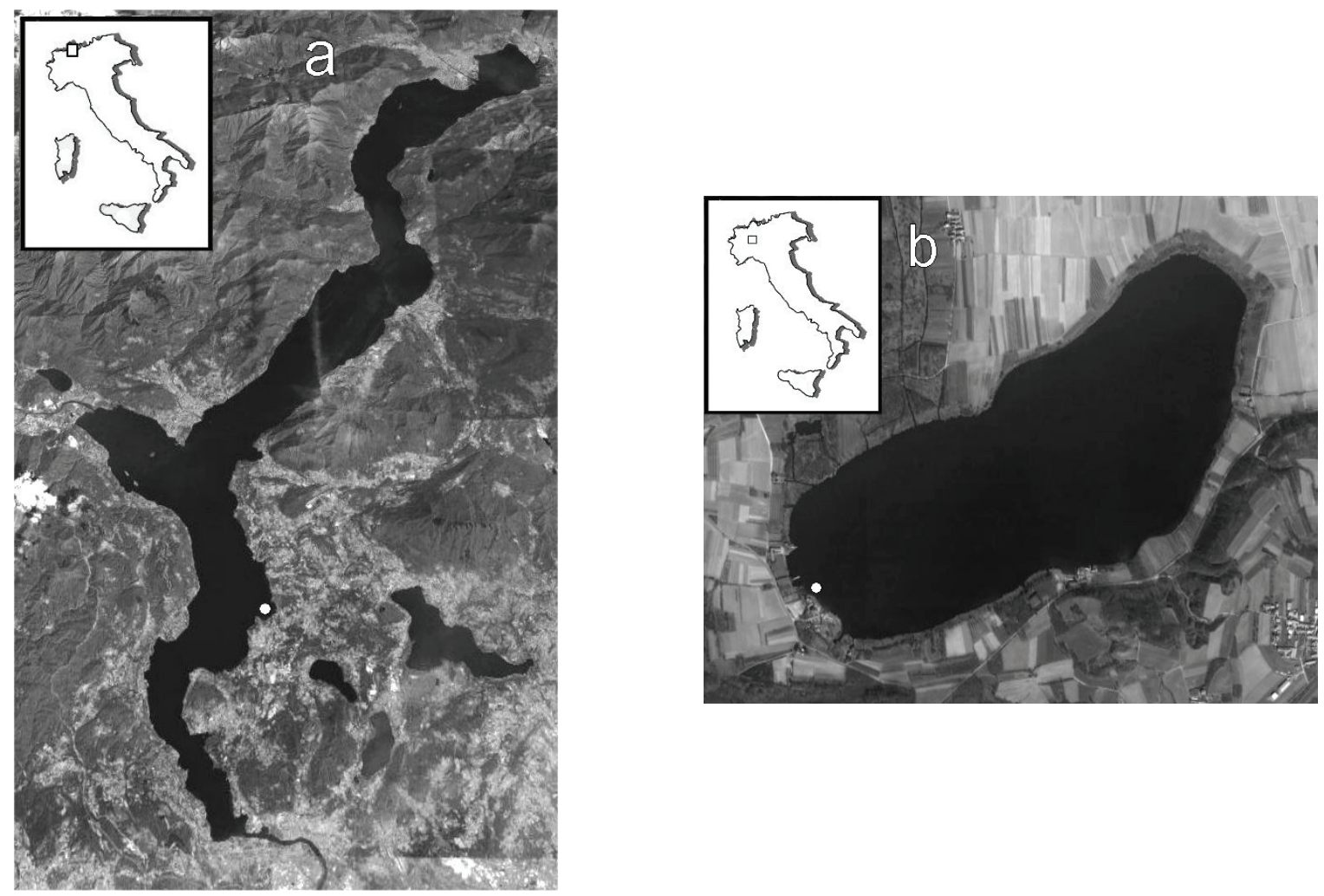

Fig. 1. Sampling stations (white spots) on Lake Maggiore (a) and Lake Candia (b).

through nutrient addition ( $\mathrm{P}$ and $\mathrm{N}$ compounds), but they failed to obtain a satisfactory result. On the contrary, a decrease of selenium in the food chain caused by a "dilution" effect was observed as a result of the enhanced tissue growth-rate.

The main subjects of this study were the following: 1) the interrelations between mercury content and mussel size; 2) the relationships between mercury, calcium and selenium; and 3) the relationships between mussels, mercury and the environment.

The increasing number of researches on these subjects published during the last decades demonstrates the importance of these studies and the need for close collaboration between ecologists and chemists.

\section{MATERIAL AND METHODS}

A detailed description of the methods used has been reported elsewhere (Ravera et al. 2007a, b).

\subsection{Material}

The sub-species used in this study was Unio pictorum mancus (Mollusca, Unionidae). This mussel has important characteristics which make it a useful indicator of trace metals in the environment (Ravera et al. $2007 \mathrm{a}, \mathrm{b}$ ); for example, it has a wide geographical distribution, a relatively long life-span, a sedentary behaviour, and it can accumulate several toxic metals without apparent damage, thanks to its various detoxification systems (Boyden 1997; Hochwald 1997; Byrne 2000).

\subsection{Study sites}

The research was carried out in two Northern Italian lakes (Tab. 1; Fig. 1): the deep Lake Maggiore (N $45^{\circ} 50^{\prime} 19^{\prime \prime}$ and $\left.\mathrm{E} 8^{\circ} 37^{\prime} 17^{\prime \prime}\right)$ and the shallow Lake Candia

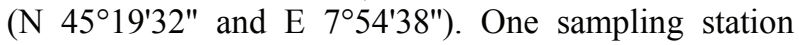
(Sabbie d'Oro) was located on the south-eastern side of oligo-mesotrophic Lake Maggiore near the village of Brebbia (Province of Varese), the other (Lido) on the south-eastern side of the eutrophic Lake Candia (Province of Turin). The main morphometric characteristics of both lakes are reported in table 1 and figure 1.

Tab. 1. Morphometric parameters of Lake Maggiore (Ambrosetti et al. 1992) and Lake Candia (Giussani \& Galanti 1992).

\begin{tabular}{lcc}
\hline & Lake Maggiore & Lake Candia \\
\hline Altitude $(\mathrm{m}$ a.s.l.) & 194 & 226 \\
Watershed area $\left(\mathrm{km}^{2}\right)$ & 6599 & 9.9 \\
Lake area $\left(\mathrm{km}^{2}\right)$ & 212.5 & 1.5 \\
Mean depth $(\mathrm{m})$ & 177 & 3.8 \\
Maximum depth (m) & 370 & 7.7 \\
\hline
\end{tabular}

In evaluating the influence of environmental conditions on the mussels, the differences between the sampling sites must be considered. For example, in the Lake Candia sampling site mussel food is very abundant, the sedimentation rate is high and the sediments are very rich in organic matter. During summer at the sediment- 
Tab. 2. Mean, standard deviation (SD) and coefficient of variation $(\% \mathrm{CV})$ of shell length $(\mathrm{mm})$, soft tissue individual dry weight $\left(\mathrm{g} \mathrm{ind}^{-1}\right)$, concentration and individual content of mercury, calcium and selenium in the soft tissues of Lake Maggiore and Lake Candia mussels.

\begin{tabular}{|c|c|c|c|c|c|c|c|c|c|}
\hline & & $\begin{array}{l}\text { length } \\
(\mathrm{mm})\end{array}$ & $\begin{array}{c}\text { weight } \\
\left(\text { g d.w. ind }^{-1}\right)\end{array}$ & $\begin{array}{c}\mathrm{Ca} \\
\left(\mathrm{mg} \mathrm{kg}^{-1}\right)\end{array}$ & $\begin{array}{c}\mathrm{Ca} \\
\left(\mu \mathrm{g} \mathrm{ind}^{-1}\right)\end{array}$ & $\begin{array}{c}\mathrm{Se} \\
\left(\mathrm{mg} \mathrm{kg}^{-1}\right)\end{array}$ & $\begin{array}{c}\text { Se } \\
\left(\mu \mathrm{g} \mathrm{ind}^{-1}\right)\end{array}$ & $\begin{array}{c}\mathrm{Hg} \\
\left(\mathrm{mg} \mathrm{kg}^{-1}\right)\end{array}$ & $\begin{array}{c}\mathrm{Hg} \\
\left(\mu \mathrm{gind}^{-1}\right)\end{array}$ \\
\hline \multirow{3}{*}{ L. Maggiore } & mean & 52.75 & 1.48 & 54714 & 93388 & 1.88 & 2.60 & 0.075 & 0.128 \\
\hline & SD & 19.81 & 0.93 & 24095 & 71666 & 0.30 & 1.51 & 0.013 & 0.063 \\
\hline & $\% \mathrm{CV}$ & 37.5 & 62.7 & 44.0 & 76.7 & 15.8 & 58.0 & 16.9 & 49.3 \\
\hline \multirow{3}{*}{ L. Candia } & mean & 73.84 & 2.38 & 22451 & 55931 & 1.51 & 3.53 & 0.033 & 0.079 \\
\hline & SD & 10.72 & 0.85 & 9571 & 35363 & 0.20 & 1.20 & 0.004 & 0.028 \\
\hline & $\% \mathrm{CV}$ & 14.5 & 35.8 & 42.6 & 63.2 & 13.5 & 33.9 & 11.5 & 35.2 \\
\hline
\end{tabular}

water interface the concentration of oxygen is very low or null and, consequently, ammonia and sulphide concentrations are sometimes very high. In the Lake Maggiore sampling station the water renewal is very active thanks to the waves, and the oxygen concentration and water transparency are optimal. The most important cause of mussel mortality is the periodical dryness of large littoral areas due to the combined effect of a decrease in lake water level and the gentle slope of the coastal zone.

Obviously, a study on one single sampling station for each lake cannot represent the ecological situation of the littoral zone of the entire lake. However, this study focused on evaluating some differences between two populations of the same species (Unio pictorum mancus) living in different habitats.

\subsection{Sampling and sample preparation}

Mussels were collected by hand at random during May 2007 from the littoral zone of Lake Maggiore (Sabbie d'Oro station) and Lake Candia ("Lido" station) (Strayer \& Smith 2003). The mussels were preserved in plastic bags in an ice-box and taken to the laboratory. The shell length was measured by callipers and the soft tissues of each individual were weighed separately and kept at $-20{ }^{\circ} \mathrm{C}$ until analysis. The shell length of the Lake Maggiore mussels ranged from 14 to $76 \mathrm{~mm}$ and that of the Lake Candia mussels from 49 to $95 \mathrm{~mm}$. 28 mussels were collected in Lake Maggiore and 25 in Lake Candia.

\subsection{Chemical analyses and instrumentation}

Standard solutions were prepared by dilution of a $100 \mathrm{mg} \mathrm{L}^{-1}$ multielement standard obtained from CPI international with the same acid amount used for sample dissolution. High-purity water (electrical resistivity $>18$ $\mathrm{M} \Omega-\mathrm{cm}$ ) was produced with a Milli-Q system. Sub-pure nitric acid was obtained with a sub-boiling system (Milestone mod. Subpure).

Mercury was measured directly by using solid/liquid atomic absorption spectrometer $\mathrm{Hg}$ analyser (Advanced Mercury Analyzer, AMA 254 mod., FKV). To analyse $\mathrm{Ca}$ and $\mathrm{Se}$, the samples were pulverised and about 500 $\mathrm{mg}$ mineralised with $8 \mathrm{~mL}$ of $\mathrm{HNO}_{3}(65 \% \mathrm{~m} / \mathrm{v})$ and 1 $\mathrm{mL}$ of $\mathrm{H}_{2} \mathrm{O}_{2}(30 \% \mathrm{~m} / \mathrm{v})$ by a microwave digestion sys- tem. The analytical determination of $\mathrm{Ca}$ was carried out with ICP-OES Perkin Elmer mod. Optima 2100 DV using a working wavelength of $317.933 \mathrm{~nm}$. Selenium analyses were carried out on ICP-MS Agilent 7500 ce mod. equipped with an ORS (Octapole Reaction System). The polyatomic interference (e.g., ${ }^{40} \mathrm{Ar}^{38} \mathrm{Ar}^{+}$) on ${ }^{78} \mathrm{Se}^{+}$was rejected using ORS with hydrogen gas $(2.2$ $\left.\mathrm{mL} \min ^{-1}\right)$. Analytical precision and accuracy were checked using standard reference materials (mussel tissue BCR 278) and replicate analysis. The quality control gave good precision $(\mathrm{SD}<5 \%$ ) for almost all samples.

\subsection{Calculations}

The $t$-test was used to evaluate the statistical significance of the difference between the values of each variable measured in Lake Maggiore and Lake Candia. The degree of variability of each variable was evaluated through the coefficient of variation $(\% \mathrm{CV})$. Linear regression was used to quantify the relationships between the variables taken into account: shell length, dry weight of soft tissues, concentration and content of $\mathrm{Hg}$, Se and $\mathrm{Ca}$ in the mussel tissues.

\section{RESULTS}

The mean values, standard deviation and coefficient of variation of the variables measured in the mussels from Lake Maggiore and Lake Candia are reported in table 2 .

The mean mussel size (shell length and soft tissues dry weight) was smaller in Lake Maggiore than in Lake Candia individuals, and the variability $(\% \mathrm{CV})$ was lower in the Lake Candia sample (Tab. 2). The mean concentration and the individual content of $\mathrm{Ca}$ and $\mathrm{Hg}$ in the tissues were higher in Lake Maggiore than in Lake Candia mussels, while the Se concentration was similar in both lakes. The $\% \mathrm{CV}$ values of $\mathrm{Ca}, \mathrm{Hg}$ and $\mathrm{Se}$ concentration and individual content were higher in Lake Maggiore than in Lake Candia mussels. To compare the metal content in the soft tissue biomass per surface unit $\left(\mathrm{m}^{2}\right)$, the population density in each lake was multiplied by the individual content of $\mathrm{Ca}, \mathrm{Hg}$ and $\mathrm{Se}$. The content of $\mathrm{Ca}$, Se and $\mathrm{Hg}$ in the mussel biomass per surface unit $\left(\mathrm{m}^{2}\right)$ is considerably greater in Lake Maggiore than in Lake Candia. Indeed, the biomass of mussels per square meter contains $438 \mathrm{mg} \mathrm{Ca}, 121 \mu \mathrm{g}$ 
Se and $5.99 \mu \mathrm{g} \mathrm{Hg}$ in Lake Maggiore, but only $387 \mathrm{mg}$ $\mathrm{Ca}, 24.46 \mu \mathrm{g}$ Se and $0.55 \mu \mathrm{g} \mathrm{Hg}$ in Lake Candia. These wide differences were due firstly to the larger population density (46.86 vs 6.93 ind $\mathrm{m}^{-2}$ ) and secondly to the higher individual content of both $\mathrm{Ca}$ and $\mathrm{Hg}$ (Tab. 2) in Lake Maggiore than in Lake Candia.

All the variables considered (shell length, tissue dry weight, concentration and individual content of $\mathrm{Ca}$, Se and $\mathrm{Hg}$ ) are significantly different in the two lakes (Tab. 2 ). The shell length and the tissue dry weight are significantly correlated. The relationships between mussel size and metal concentrations, and those between the concentrations of different metals in the same mussels, are schematized in figures 2 and 3. In Lake Maggiore the relationships between mussel size (shell length and tissue dry weight) and tissue metal concentrations are positive for $\mathrm{Ca}$, negative for $\mathrm{Se}$, and not significant for Hg (Fig. 2). In Lake Candia the relationship is negative for $\mathrm{Se}$, and not significant for $\mathrm{Ca}$ and $\mathrm{Hg}$. In Lake Maggiore a negative relationship was found between $\mathrm{Ca}$ and Se concentrations in mussel tissue, while no significant relationship was found between $\mathrm{Ca}$ and $\mathrm{Hg}$ and $\mathrm{Se}$ and $\mathrm{Hg}$. In Lake Candia, $\mathrm{Ca}$ concentration is negatively related to both $\mathrm{Se}$ and $\mathrm{Hg}$, while no significant relationship was found between Se and $\mathrm{Hg}$.

\section{DISCUSSION AND CONCLUSIONS}

\subsection{Interrelations between mercury concentration and mussel size}

The concentration of metal in mussel tissues is the result of a balance between the tissue growth-rate and the metal accumulation rate. If the tissue growth rate exceeds the accumulation rate, the concentration of mercury decreases with mussel size, while the opposite occurs when the mussel grows more slowly than the rate of metal accumulation (Boyden 1977). In the first case, even when there is a decrease in the concentration of the metal, the metal content may increase. The lack of a statistically significant relationship between the metal concentration and a biological variable generally testifies to the mutual independence between the variables. However, in some cases this independence is not real, but may be due to an excessively narrow size range between the smallest mussel and the largest one. If the size range of mussels in a sample is relatively narrow, it is quite probable that the animals' ages are not different enough to result in a significant difference in the concentration of metal accumulated over time (e.g., Kwan et al. 2003).

The size (length of the shell or weight of tissues) of the mussel seems to be one of the most important biological variables influencing metal concentrations in mussel tissues. Many studies, most of them on marine mussels, deal with this relationship, but the question is still open. In fact, there is general agreement on the significant and positive relationship between metal content in the tissues and mussel size, whilst the relationship between metal concentration and mussel size may be positive, negative or not statistically significant. Some selected examples may illustrate this variability.

Fowler et al. (1978) observed a negative relationship between mercury concentration in Mytilus galloprovincialis and the size of the animal. Conversely, Wiesner et al. (2001) noted a positive relationship between the size of Dreissena polymorpha and mercury concentration. Researching the influence of the size of Mytilus galloprovincialis on the concentration and content of 8 elements $(\mathrm{Hg}, \mathrm{Cd}, \mathrm{Pb}, \mathrm{Cr}, \mathrm{Ni}, \mathrm{As}, \mathrm{Cu}$ and $\mathrm{Zn})$ in the tissues of the mussel, Saavedra et al. (2004) found the following results: a) a positive relationship between element content and shell length; b) the concentration of the elements in the tissues did not seem to depend on the shell length; and c) a positive relationship between the weight of soft tissues and shell length.

Kwan et al. (2003) carried out a study to evaluate the influence of Dreissena polymorpha size on the concentration and content of 11 elements. Their results show that the elements may be assessed in two groups. The elements of the first group (As, $\mathrm{Pb}, \mathrm{Mn}, \mathrm{Se}$ and $\mathrm{Hg}$ ) show no significant relationship between tissue weight and concentrations, while a positive correlation between elements content in the tissues and their wet weight was observed. The elements of the second group $(\mathrm{Cd}, \mathrm{Ni}, \mathrm{Cr}$, $\mathrm{Ca}, \mathrm{Zn}$ and $\mathrm{Cu}$ ) were characterized by a positive correlation between elements concentration, as well as metal content, and mussel weight. In addition, the concentrations of these elements were significantly correlated between each other.

Our study clearly revealed that, in both lakes, the individual mercury content $\left(\mu \mathrm{g} \mathrm{ind}^{-1}\right)$ in mussel tissues increases with mussel size (shell length and tissue weight). In contrast, mercury concentration $\left(\mathrm{mg} \mathrm{kg}^{-1}\right)$ is independent of mussel size, except for a tendency towards a decrease of $\mathrm{Hg}$ concentration with mussel weight in Lake Candia. This negative relationship is commonly interpreted as the result of a tissue growthrate exceeding the $\mathrm{Hg}$ uptake-rate, with a consequent "dilution" of the mercury in the tissues (e.g., Boyden 1977).

\subsection{Relationships between mercury, calcium and selenium}

Several marine and freshwater bivalves (e.g., Mytilus, Dreissena, Unio, Anodonta) can survive and reproduce in environments heavily contaminated by toxic metals. This is due to the mussels' capacity to prevent or minimize, at least in part, the effects produced by toxic elements. For example, the elements may be removed from the organism by excretion, or neutralized by formation of organo-metals, but most of the metal is sequestered by the extracellular calcareous granules present in the soft tissues (Boyden 1977; Jeffree \& Simpson 1986; Jeffree 1988; Jeffree et al. 1993; Moura et al. 1999). 


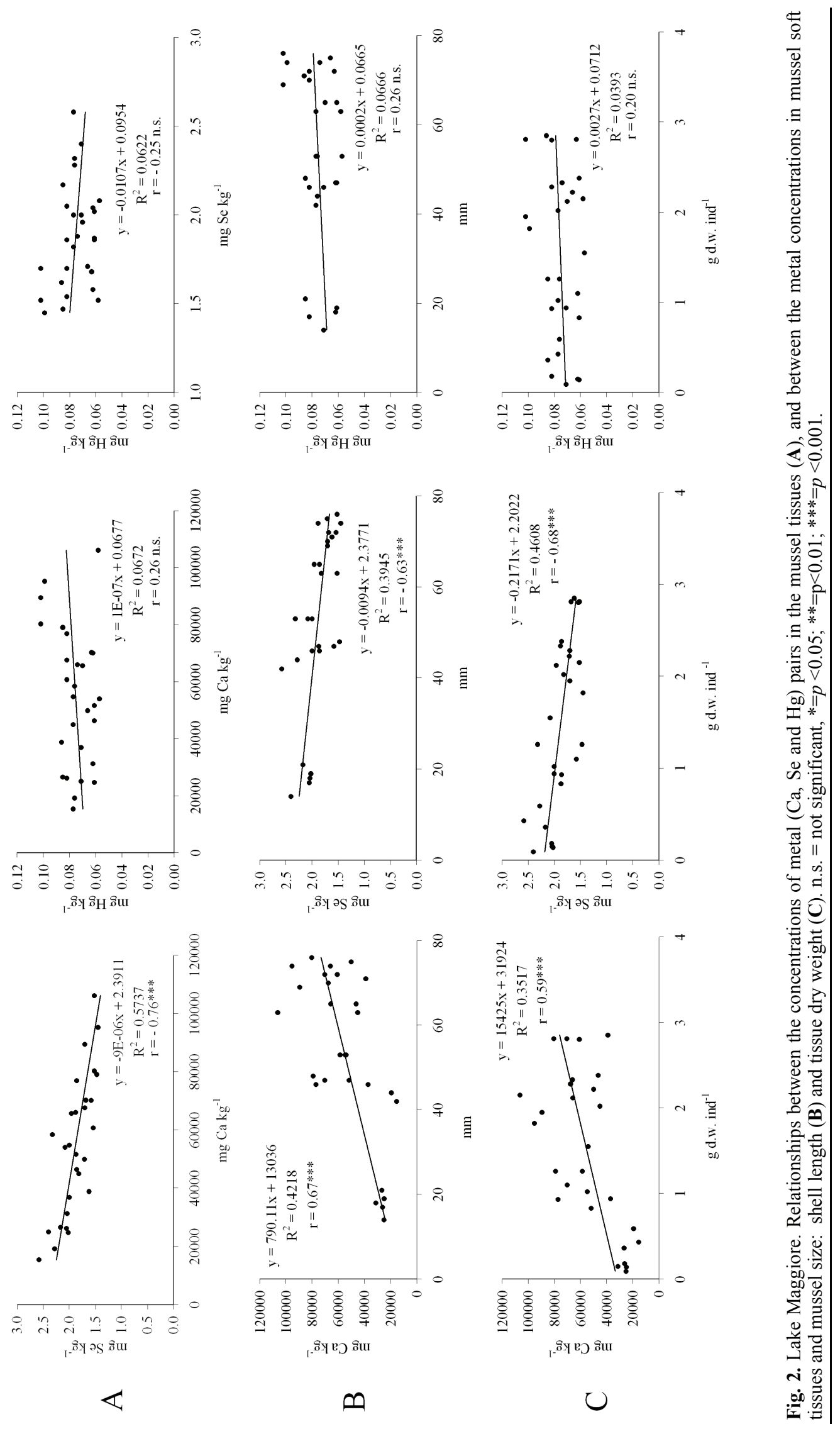



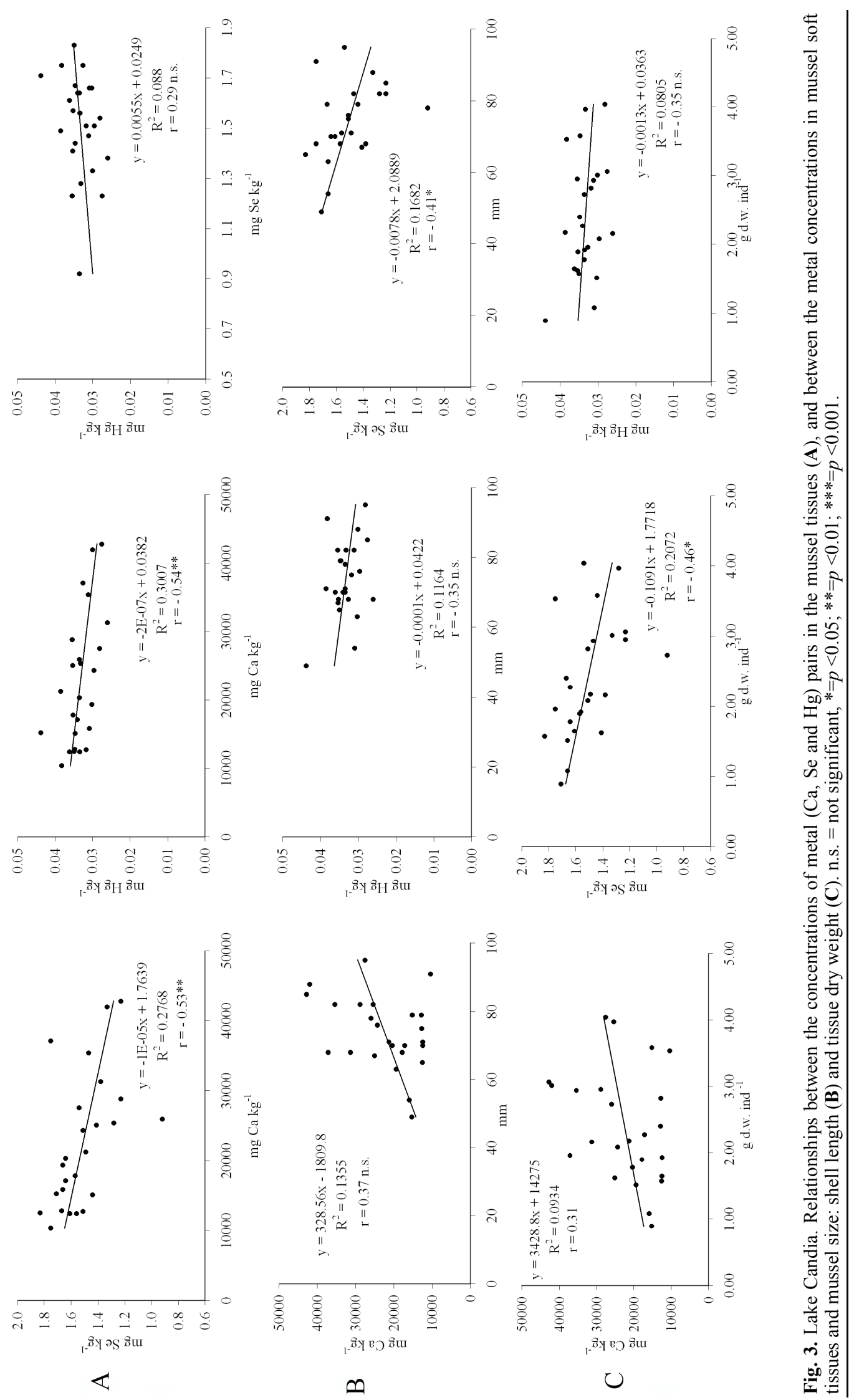
These granules are abundant in the tissues and, according to Byrne (2000), their total dry weight is equivalent to that of the soft tissues. Because of the small size $(0.5 \div 2.5 \mu \mathrm{m})$ and abundance of the granules, the free surface of the total granules is very large; this facilitates the links between the granules and several metals analogous to calcium. Jeffree et al. (1993) estimate that $92-97 \%$ of the metals present in the mussel is tied to the granules; Markich et al. (2001) calculated percentages ranging from $74 \%$ to $90 \%$. This means that the granules are an important calcium store and, due to their low solubility and great capacity to sequester metals, represent an effective defence for a bivalve which may live in metal-contaminated environments (Jeffree \& Simpson 1986; Jeffree 1988; Jeffree et al. 1993). On this basis Byrne \& Vesk (2000) and Markick et al. (2001) proposed the use of granules as a valuable indicator of metal pollution level.

The relationship between $\mathrm{Ca}$ and $\mathrm{Hg}$ concentrations in Lake Maggiore mussels is not significant, suggesting that $\mathrm{Ca}$ has no evident influence on the $\mathrm{Hg}$ concentration (Fig. 2). In contrast, for Lake Candia mussels this relationship is significant and negative, i.e. the behaviour of $\mathrm{Ca}$ is antagonistic to $\mathrm{Hg}$ (Figs 2 and 3).

Since the 1960s the protective action of selenium against the toxic effects of mercury has been the subject of many researches on terrestrial animals and fish; however, the information on aquatic invertebrates (e.g., mussels) is rather poor (e.g., Pelletier 1986; Micallef \& Tyler 1987; Wang et al. 2004). Belzile et al. (2006) described the effects of selenium on mercury uptake in net-plankton, fishes and macroinvertebrates. Rudd et al. (1980) and Turner \& Rudd (1983), from the results of experiments carried out in enclosures, concluded that the effects of mercury in freshwater organisms are delayed when the selenium concentration in the water is very high. Micallef \& Tyler (1987) studied the effects of mercury and selenium in Mytilus edulis. Chen et al. (2001) calculated a negative relationship between selenium and mercury concentrations in the muscle of bivalves. Pelletier (1986) observed that the selenium accumulation in Mytilus increases in the presence of mercury, but the mercury accumulation is not influenced by selenium. In conclusion, the opinion of the authors on the protection afforded by selenium from the effects of mercury is not unanimous. We failed to find any relationship between the selenium and mercury concentrations in Unio populations of both lakes, so that we have to conclude that they seem to be independent of each other (Figs 2 and 3). According to Belzile et al. (2006), to obtain a negative relationship, the total mercury must be substituted by the organic forms (mainly methylmercury $\mathrm{MeHg}$ ), because a part of total mercury may be not available to organisms.

A negative relationship was found between $\mathrm{Ca}$ and $\mathrm{Se}$ in both lakes. Therefore, we may speculate that selenium can affect mercury concentration not directly but through its effects on calcium concentration, which in turn, at least in Lake Candia, seems to reduce mercury accumulation.

\subsection{Relationships between mussel, metals and environment}

The influence of a population on the cycle of elements in the environment is also proportional to the amount of element contained in its biomass.

The mercury content in mussel biomass was about eleven-fold higher in Lake Maggiore $\left(5.99 \mu \mathrm{g} \mathrm{m}^{-2}\right)$ than in Lake Candia $\left(0.55 \mathrm{\mu g} \mathrm{m}^{-2}\right)$ due to a 1.8 higher individual content $\left(0.128 \mu \mathrm{g}\right.$ ind $^{-1}$ and $0.079 \mu \mathrm{g}$ ind $^{-1}$ respectively) as well as about a 7 -fold higher population density. The mean local population density is 46.86 ind $\mathrm{m}^{-2}$ in Lake Maggiore but only 6.93 ind $\mathrm{m}^{-2}$ in Lake Candia (Ravera et al. 2007a). Even though the individual soft tissue weight was greater in mussels from Lake Candia (2.38 $\left.\mathrm{g} \mathrm{ind}^{-1}\right)$ than those in Lake Maggiore (1.48 $\mathrm{g} \mathrm{ind}^{-1}$ ), the individual content was 0.62 -fold of that in Lake Maggiore, probably because of the diluting effect caused by a higher individual growth rate under eutrophic conditions (Ravera et al. 2007b).

Differences in growth rate, as well as in population density, are obviously the result of the interaction between environmental conditions and organism adaptation, and should obviously reflect the direct and/or indirect effects of the trophic level of the environment. Eutrophication is one of the commonest and most efficient causes of ecosystem change, and consequently also affects mussel populations (e.g., Agrell 1948; Patzner \& Müller 2001). Due to its complex life cycle, Unio pictorum mancus is influenced by different variables during its successive life stages (glochidium, parasitic stage, juvenile and adult). For instance, the survivorship of glochidia is dependent on fish which is both their predator and their host, while juvenile survivorship is strongly influenced by substratum quality and by the chemistry of the sediments. Populations of the same species (Unio pictorum mancus) adapted to environments with very different trophic levels, such as Lake Maggiore and Lake Candia, show marked biological and chemical differences (Ravera et al. 2007a, b). We might advance some hypotheses to explain these differences. Even though individual growth is enhanced by higher food availability in Lake Candia, another effect of eutrophic conditions could be to reduce juvenile survivorship. In fact, Agrell (1948) demonstrated that juvenile mortality can be so high that it strongly reduces population density, and Hochwald (1997) showed that juveniles are very sensitive to environmental stresses and, particularly, to indirect as well as direct effects of eutrophication. We showed in a previous research that the relative proportion of small individuals is lower in Lake Candia than in Lake Maggiore, supporting the hypothesis of a reduced recruitment (Ravera et al. 2007a). Since we can exclude the effect of other envi- 
ronmental stresses (such as toxic pollution, heavy predation impact or wide water level fluctuations) on the Lake Candia population, recruitment failure is probably attributable to the effects of eutrophication (such as oxygen depletion, increased ammonia and sulphide concentration, fine sediment resuspension), probably due to post-settlement mortality in the sediment (Helson \& Gardner 2004). In contrast, the Lake Maggiore population experiences a lower trophic level and is exposed to waves which provide continuous water renewal, assuring a year-round high oxygen concentration. Juvenile recruitment can be expected to be higher than in Lake Candia, a hypothesis which is confirmed by the higher proportion of young individuals in the population. The major cause of mussel mortality is the fact that a fairly large littoral area is subject to drying up, with a reduction of water level occurring once or twice per year. A comparison of the size structure of the living population with that of dead mussels along the lake shore showed that this kind of mortality is not size dependent and does not affect population age structure. Even though thousands of individuals die following these drought events, a very high and relatively constant population density is maintained over years, providing further support to the hypothesis of a very high annual recruitment (Ravera et al. 2007a). It therefore seems logical to conclude that lake trophy and water renewal affect population density and individual growth rate, and ultimately determine their impact on biogeochemical cycles by regulating the mussel standing stock.

\section{ACKNOWLEDGEMENTS}

We would like to thank Dr. L. Guzzi (CESIResearch, Italy), Prof. J.L. Jamet (Universitè de ToulonVar, France), Prof. D. Lajus (St. Petersburg State University, Russia) and Prof. K.O. Nagel (Bad Krozingen, Germany) for their comments which improved the manuscript. We would like to express our grateful thanks to Mrs Sandra Spence for the careful English revision.

\section{REFERENCES}

Agrell, J. 1948. The shell morphology of some Swedish unionids as affected by ecological conditions. Ark. Zool., 41: $1-30$.

Ambrosetti, W., Barbanti, L., Mosello, R. \& A. Pugnetti. 1992. Limnological studies on the deep southern alpine lakes Maggiore, Lugano, Como, Iseo and Garda. in: Guilizzoni, P. Tartari, G. \& G. Giussani (Eds), Limnology in Italy. Mem Ist. ital. Idrobiol., 50: 117-140.

Belzile, N., Chen Y.W., J.M. Gunn, J. Tong,, Y. Alaire, T. Delonchamp \& C.Y. Lang. 2006. The effect of selenium on mercury assimilation by fresh water organisms. Can. J. Fish. Aquat. Sci., 63: 1-10.

Boyden, C.R. 1977. Effect of size upon metal content of shellfish. J. Mar. Bio. Assoc. U.K., 57: 675-714.

Byrne, M. 2000. Calcium concretions in the interstitial tissues of the Australian freshwater mussel Hyridella depressa (Hyriidae). In: E.M. Harper, J.D. Taylor \& J.A. Crame (Eds), The Evolutionary Biology of the Bivalvia. Geological Society, London, Special Publications, 177: 329-337.
Byrne, M. \& P.A. Vesk. 2000. Element composition of mantle tissue granules in Hyridella depressa (Unionida) from the Hawkesbury - Nepean River system, Australia: influence from catchment chemistry. Aust. J. Mar. Freshwater Res., 51: 183-192.

Chen, Y.W., N. Belzile \& M. Gunn. 2001. Antagonistic effect of selenium on mercury assimilation by fish population near Sudbury metal smelters? Limnol. Oceanogr., 46: 1814-1818.

Fowler, S.W., M. Heyraud \& J. La Rosa. 1978. Factor affecting methyl and inorganic mercury dynamics in mussels and shrimp. Mar. Biol., 46: 267-276.

Giussani, G. \& G. Galanti. 1992. Experience in eutrophication recovery by biomanipulation. in: Guilizzoni, P. Tartari, G. and G. Giussani (Eds), Limnology in Italy. Mem Ist. ital. Idrobiol., 50: 397-416.

Hochwald, S. 1997. Populationsökologie der Bachmuschel (Unio crassus). Bayreuther Forum Ökologie, 50: 1-166.

Helson, J.G. \& J.P.A. Garden. 2004. Contrasting patterns of mussel abundance at neighbouring sites: does recruitment limitation explain the absence of mussels on Cook Strait (New Zeeland) shores? J. Exper. Mar. Biol., 312: 285-298.

Jeffree, R.A. 1988. Experimental comparison of radium-226 and calcium-45 kinetics in the freshwater mussel Velesunio angasi. Ver. Int. Ver. Theor. Angew. Limnol., 23: 2193-2201.

Jeffree, R.A. \& R.D. Simpson. 1986. An experimental study of the uptake and loss of radium-226 by the tissue of the freshwater Valesunio angasi under varying $\mathrm{Ca}$ and $\mathrm{Mg}$ water concentrations. Hydrobiologia, 139: 59-80.

Jeffree, R.A., S.J. Markich \& P.L. Brown. 1993. Comparative accumulation of alkaline-earth metals by two freshwater mussel species from the Nepean River, Australia: consistencies and a resolved paradox. Aust. J. Mar. Freshwater Res., 44: 609-634.

Kwan, K.H.M., H.M. Chan \& Y. De Lafontaine. 2003. Metal contamination in zebra mussels (Dreissena polymorpha) along the St. Lawrence River. Environ. Monit. Assess.: 193-219.

Markich, S.J., P.L. Brown \& R.A. Jeffree. 2001. Divalent metal accumulation in freshwater bivalves: an inverse relationship with metal phosphate solubility. Sci. Total Environ., 275: 27-41.

Micallef, S. \& P.A. Tyler. 1987. Preliminary observation of the interactions of mercury and selenium in Mytilus edulis. Mar. Pollut. Bull., 18: 180-185.

Moura, G., Guedes, R. \& J. Machado. 1999. The extracellular mineral concretions in Anodonta cygnea, L.: different types and manganese exposure-caused changes. J. Shellfish Res., 18: 645-650.

Patzner, R.A. \& D. Müller. 2001. Effects of eutrophication on Unionids. In: G. Bauer \& K. Watchtler (Eds), Ecology and evolution of freshwater mussels Unionoida. SpringerVerlag, Berlin. Ecological Studies, 145: 327-335.

Pelletier, E. 1986. Modification de la bioaccumulation du selenium chez Mytilus edulis en presence du mercure organique et inorganique. Can. J. Fish. Aquat. Sci., 43: 203210.

Ravera, O. 2008.An index for estimating the potential impact on the environment of the pollutant content in aquatic populations. J. Limnol., 67(1): 70-74.

Ravera, O., A. Frediani \& N. Riccardi. 2007a. Seasonal variations in population dynamics and biomass of two Unio pictorum mancus (Mollusca, Unionidae) populations from two lakes of different trophic state. J. Limnol., 66(1): 15-27.

Ravera, O., G.M. Beone, P.R. Trincherini \& N. Riccardi. 2007b. Seasonal variations in metal content of two Unio pictorum mancus (Mollusca, Unionidae) populations from two lakes of different trophic state. J. Limnol., 66(1): 28-39.

Rudd, J.W.M., M.A. Turner, B.E. Townsend, A. Swick \& A. Furutani. 1980. Dynamics of selenium in mercury con- 
taminated experimental freshwater ecosystems. Can. J. Fish. Aquat. Sci., 37: 848-857.

Saavedra, Y., A. Gonzales, P. Fernandez \& J. Blanco. 2004. The effect of size on trace metal levels in raft cultivated mussels (Mytilus galloprovincialis). Sci. Total. Environ., 318: 115-124.

Strayer, D.L. \& D.R. Smith. 2003. A guide to sampling freshwater mussel populations. American Fisheries Society Monograph, 8. American Fishery Society, Bethesda, Maryland (USA).

Turner, M.A. \& J.W.M. Rudd. 1983. The English-Wabigoon River system: III. Selenium in lake enclosure: its geo- chemistry, bioaccumulation, and ability to reduce mercury bioaccumulation. Can. J. Fish. Aquat. Sci., 40: 2228-2240.

Wang, W.X., R.S.K. Wong, J. Wang \& Y.F. Yen. 2004. Influences of different selenium species on the uptake and assimilation of $\mathrm{Hg}(\mathrm{II})$ and methylmercury by diatoms and green mussels. Aquat. Toxicol., 68: 39-50.

Wiesner, L., B. Günther \& C. Fenske. 2001. Temporal and spatial variability in the heavy-metal content of Dreissena polymorpha (Pallas) (Mollusca: Bivalvia) from the Kleines Haff (Northern Germany). Hydrobiologia, 443: $137-145$.

Received: February 2009

Accepted: June 2009 